\title{
Regional Patterns and Determinants of Commuting Between Rural and Urban India
}

\author{
Vasavi Bhatt $^{1} \cdot$ S. Chandrasekhar ${ }^{1} \cdot$ Ajay Sharma $^{2}$ \\ Published online: 14 October 2020 \\ (c) Indian Society of Labour Economics 2020
}

\begin{abstract}
Despite an increase in the number of workers commuting between rural and urban areas, much of the literature on worker mobility continues to be migration centric. This paper establishes the importance of rural-urban commuting in India. As per estimates from Periodic Labour Force Survey 2018-2019, an estimated 18.8 million individuals living in rural are working in urban India and the share of earnings from urban in total non-farm rural earnings is $19.3 \%$. Among all rural workers, $7.3 \%$ are rural-urban commuters while only $2.1 \%$ of urban workers are urban-rural commuters. We document large variations at the sub-national level. Our results from a multinomial model to understand the factors associated with commuting highlight the importance of lagged regional unemployment rate. A high rural unemployment rate acts as a push factor, and a low urban unemployment rate acts as a pull factor for rural-urban commuting. The urbanness of occupations in a region is also an important correlate of commuting. The paper concludes by highlighting the need to prioritize questions in India's labour force survey that would help understand the nature of labour mobility and strength of rural-urban linkages.
\end{abstract}

Keywords Labour mobility $\cdot$ Commuting $\cdot$ Rural-urban linkages $\cdot$ Classification of jobs $\cdot$ India

JEL Classification $\mathrm{J} 21 \cdot \mathrm{J} 61 \cdot \mathrm{R} 12 \cdot \mathrm{R} 23$

\footnotetext{
S. Chandrasekhar

chandra@igidr.ac.in

Vasavi Bhatt

vasavi@igidr.ac.in

Ajay Sharma

ajays@iimidr.ac.in

1 Indira Gandhi Institute of Development Research, Gen A K VaidyaMarg, Goregaon (East), Mumbai 400065, India

2 Indian Institute of Management, Indore, India
} 


\section{Introduction}

Three key factors, viz. distribution of economic activity and availability of jobs over space, distance between residence and job location, and the wage differential between source and destination, together determine the decision of workers to either migrate or commute. In addition to these factors, access to transportation, time and monetary cost of transport are important correlates of the decision to commute to work. While the theoretical models on place of residence and job location are fairly standard, ${ }^{1}$ the empirical literature on commuting, in context of developing countries is fairly limited, especially between rural and urban areas. In fact, to this date, much of the literature on worker mobility continues to be migration centric. This is despite the fact that there has been an increase in the number of workers commuting between rural and urban areas. It is also true that the number of daily commuters is as large if not larger than either seasonal or permanent migrants in any year (Chandrasekhar et al. 2017). Additionally with the dependence on non-farm employment and earnings among rural households, commuting has become far more important channel to be understood and facilitated.

This paper is a contribution to the literature on two-way rural-urban commuting by workers. We analyse data from Periodic Labour Force Survey (PLFS) 2018-2019 which was conducted by India's National Statistical Office. In 2018-2019, we estimate that 18.8 million individuals living in rural areas were working in urban India, for 2.3 million urban workers the place of work was rural, and 9.7 and 7.8 million rural and urban workers, respectively, had no fixed place of work. These estimates of commuting are lower bound estimates since they do not include workers commuting within rural areas or inter-city commuters. The importance of rural-urban commuting is evident from the fact that the share of earnings from urban areas in total nonfarm rural earnings is $19.3 \%$ in $2018-2019$.

The phenomenon of rural-urban commuting is evident in a diverse group of developing countries. ${ }^{2}$ Various studies have highlighted the importance of proximity to the city for the mobility patterns of rural workers. A recent study in North East Thailand revealed that individuals are willing to travel up to $20 \mathrm{~km}$ from the villages in order to work in the factory clusters (Shirai et al. 2019). In Indonesia, rural-urban commuting has been observed within $60-\mathrm{km}$ periphery of industrialized cities (Douglass 2007). A study of two villages from Bihar in India clearly brought out the importance of distance to the city and connectivity (Datta et al. 2014). They find that in Chandkura, a village near Patna, the capital of Bihar, workers were commuting up to $30 \mathrm{~km}$ every day while migration was observed in Mahisham, a village which was not near a large city.

Apart from proximity to cities, an important determinant of commuting is the wage gradient, i.e. the extent to which wages decline as distance to the city

\footnotetext{
1 The theoretical models have sought to explain one-way commuting from residence location in the suburban areas to the central business district (Alonso 1964; Mills 1967; Muth 1969) and commuting patterns in cities with multiple job locations (Brueckner et al. 1999; White 1988).

2 See Sharma and Chandrasekhar (2014) for a discussion.
} 
increases. The wage gradient is also a function of the distribution of jobs by industry and occupations along the rural-urban continuum. Based on analysis of data from India Human Development Survey 2004-2005, Sharma (2016) identifies the following patterns in the context of India. First, in locations closer to the city, one is more likely to observer regular wage or salaried individuals or self-employed rather than workers being engaged in agricultural activities. A stylized fact is that income from non-farm activities decreases as distance from urban settlements increase. This pattern is also observed in other countries. Proximity to urban centres is associated with an increase in non-farm employment in Ghana (Diao et al. 2019). Sharma and Chandrasekhar (2016) find that the average wages of rural-urban commuters is the highest followed by workers living and working in rural areas, with rural workers with no fixed place of work having the lowest average wages. Similar results are evident in China. Duvivier et al. (2013) find wages to be higher by $15 \%$ in the vicinity of the city as compared to remote hinterland workers. The wage differential and unemployment rate are related. Sharma and Chandrasekhar (2014) find that regional rural and urban unemployment rates and rural-urbanwage differentials are important push and pull factors in the decision to commute.

Another consistent finding across developed and developing countries is the relevance of nature of jobs to commuting decisions. Needless to say, the labour market in developed countries greatly varies from that in developing countries. Workers in developed countries have the flexibility in time and place of work which in turn may influence their commuting patterns (Green et al. 1999, Andersson et al. 2018). Commuting has been associated with high skilled workers (Artis et al. 2000; Andersson et al. 2018; Rowe and Bell 2020). Concentration of certain sectors or occupations can influence the commuting behaviour in a region. Rowe and Bell (2020) find that in Chile the most important driver of long-distance commuting is the location and characteristics of mining and construction sector. In the last three decades, India has seen relocation of investments across the rural and the urban (Chakravorty and Lall 2007) resulting in a redistribution of economic activity. These changes can be traced to the process of economic reform ushered in 1991 and in particular relaxation of policies on industrial location. Based on analysis of data from Annual Survey of Industries and Surveys of Unorganized Sector, Ghani et al. (2012) find that formal manufacturing has shifted from urban to rural areas and the converse holds for informal manufacturing. Another study finds dispersal of manufacturing activity with some evidence of higher growth in low-density manufacturing districts (Desmet et al. 2015). This churning has led to delocalization of jobs, emergence of new centres of activity and a myriad of commuting patterns at the sub-national level in India.

While data from cross sectional surveys are useful in establishing patterns in commuting, they lack the richness offered by Census data or panel data. While limited information was collected on commuting as part of Census of India 2011, the developed countries have collected detailed data on commuting as part of successive Censuses. Green and Meyer (1997) who analyse data from Canadian Census 1991 found that rural population had remained constant, job opportunities had declined, and this led to workers commuting to urban areas. They refer to the work by Everitt and Gill (1993) who document the emergence of rural "dormitory towns" where 
the urban workers lived. While such rich descriptions are not possible in the Indian context with either survey or census data, there are insights available from small area panel studies. Heyer (2013) documents that during the course of development of Tiruppur, in the southern Indian state of Tamil Nadu, as a textile hub, there was a change in land use patterns, villages closer to cities underwent transformations, real estate sector grew, and there was an improvement in transport and communications. She characterizes these villages as "important commuter bases for relatively unskilled labour” (p. 311). Rural labour comprising first-generation non-agricultural workers provided cheap unskilled labour to the textile units since the wages were higher than earnings provided by agriculture.

The above discussion on commuting patterns of workers, especially between rural and urban areas, highlights that rural labour market conditions, distribution of economic activities, access to urban areas play an important role in the decision to commute. In this paper, we focus on understanding the patterns and determinants of commuting between rural and urban areas to contribute to the existing literature on mobility of workers in developing counties and to complement the studies on migration patterns in the context of India. For our analysis, we use nationally representative survey data from PLFS for the year 2018-2019. The rest of the paper is structured as follows. In Section 2, we discuss the data set, and in Section 3, we provide key estimates and regional patterns of commuting. In Section 4, we describe the empirical model for determinants of commuting and the main results. Section 5 discusses the policy implications and concludes.

\section{Data}

We use unit level data from PLFS 2018-2019. Before proceeding further, it would be useful to mention one key feature of the survey. While rural households are visited once during the course of the survey year, the urban households are revisited. The report published by National Statistical Office corresponding to PLFS mentions that indicators like labour force participation rate, worker population ratio, and distribution of workers by principal status, industry of work and occupation of workers should be calculated using only the data from the first visit for urban households (Table 2, National Statistical Office 2020). Hence, the analysis in this paper is based on data from the first visit for both rural and urban households.

The PLFS covered 55,812 rural and 45,767 urban households. Information was canvassed on demographic and other particulars of 239,817 and 180,940 individuals living in rural and urban India, respectively. Estimates can be generated from PLFS separately for rural and urban areas of each state. The PLFS is considered by researchers to be representative at the NSS region although NSO does not present estimates at the level of NSS region in its report.

For all members of the household, the principal activity status is available. The principal activity status can be broadly grouped into following categories: selfemployed, regular salaried/wage employee, casual wage labour, unemployed, and not in the workforce. The location of place of work is sought only for those engaged in industry groups $014,016,017$ and divisions $02-99$, i.e. this information is not 
Table 1 Classification of non-farm workers in rural and urban India by place of residence and work

\begin{tabular}{|c|c|c|c|c|c|}
\hline \multirow[t]{2}{*}{ Place of residence } & \multirow[t]{2}{*}{ Place of work } & \multicolumn{2}{|l|}{ 2018-2019 } & \multicolumn{2}{|l|}{ 2011-2012 } \\
\hline & & Number (million) & Share $(\%)$ & Number (million) & Share $(\%)$ \\
\hline \multirow[t]{5}{*}{ Rural } & Not applicable ${ }^{+}$ & 135.4 & 52.7 & 168.6 & 60.6 \\
\hline & Rural & 92.9 & 36.2 & 97.1 & 34.9 \\
\hline & Urban & 18.8 & 7.3 & 8.7 & 3.1 \\
\hline & No fixed place & 9.7 & 3.8 & 3.9 & 1.4 \\
\hline & Total workers & 256.8 & 100 & 278.3 & 100 \\
\hline \multirow[t]{5}{*}{ Urban } & Not applicable ${ }^{+}$ & 4.3 & 3.9 & 5.4 & 5.1 \\
\hline & Rural & 2.3 & 2.1 & 3.6 & 3.4 \\
\hline & Urban & 95.4 & 86.8 & 90.8 & 84.6 \\
\hline & No fixed place & 7.8 & 7.1 & 7.5 & 6.9 \\
\hline & Total workers & 109.8 & 100 & 107.3 & 100 \\
\hline
\end{tabular}

Source: Calculations from unit level data PLFS 2018-19 and survey on employment \& unemployment 2011-12

${ }^{+}$Location of place of work is sought only for those in industry groups 014, 016, 017 and divisions 0299 , i.e. workers not engaged in farming

sought for those who are engaged in growing of perennial or non-perennial crops, plant propagation or mixed farming. In the rest of the paper, we refer to the workers for whom location of work is a relevant question as workers not engaged in farming.

The PLFS has information on place of residence of an individual (rural, urban) and the place of work (rural, urban, no fixed place of work). Given this classification, we can group workers in rural and urban India into four mutually exclusive categories (see Table 1). Among all rural resident workers, $7.3 \%$ are t commuters while only $2.1 \%$ of urban resident workers are urban-rural commuters. The share of workers with no fixed place of work is greater in urban than in rural areas.

There has been a large and inconclusive debate on whether estimates from Employment and Unemployment Survey (EUS) 2011-2012 and Periodic Labour Force Surveys are comparable or not. Without getting into technicalities of the debate, we believe that it would not be incorrect to compare select estimates of commuting from these two surveys. ${ }^{3}$ In Table 1, we have presented the estimates for 2011-2012 and PLFS 2018-2019. The number of rural-urban commuters has more than doubled and that of rural no fixed place workers increased by nearly two and half times. Since the data pertains to the same decade, it is unlikely that the estimates are affected by reclassification of rural as urban areas or growth of census towns. The distribution of non-farm workers in rural and urban by place of residence and work in each state is given in "Appendix Table 11". The change in distribution of non-farm workers by place of residence and place of work across the 2 years is given in Table 2. Clearly, there is an increase in the share of rural-urban workers

\footnotetext{
3 Interestingly, in the PLFS report, the aggregate estimates of PLFS surveys are compared with estimates from earlier rounds of employment and unemployment surveys.
} 
Table 2 Classification of non-farm workers in rural and urban India by principal status, place of residence and work

\begin{tabular}{|c|c|c|c|c|c|c|c|c|}
\hline & \multicolumn{4}{|c|}{ Place of residence: rural } & \multicolumn{4}{|c|}{ Place of residence: urban } \\
\hline & Rural & Urban & No fixed place & Total & Urban & Rural & No fixed place & Total \\
\hline \multicolumn{9}{|l|}{ Year: 2018-2019 } \\
\hline Self-employed & 84.5 & 7.8 & 7.7 & 100 & 85.2 & 2.8 & 12.1 & 100 \\
\hline Regular salaried/wage & 67.1 & 29.5 & 3.4 & 100 & 96.7 & 1.7 & 1.6 & 100 \\
\hline Casual wage labour & 75.3 & 12.3 & 12.3 & 100 & 80.0 & 2.7 & 17.3 & 100 \\
\hline All & 76.5 & 15.5 & 8.0 & 100 & 90.4 & 2.2 & 7.4 & 100 \\
\hline \multicolumn{9}{|l|}{ Year: 2011-2012 } \\
\hline Self-employed & 92.0 & 2.9 & 5.1 & 100 & 82.7 & 4.2 & 13.2 & 100 \\
\hline Regular salaried/wage & 84.1 & 14.2 & 1.8 & 100 & 95.2 & 3.0 & 1.8 & 100 \\
\hline Casual wage labour & 87.4 & 9.7 & 2.9 & 100 & 87.1 & 3.7 & 9.2 & 100 \\
\hline All & 88.5 & 8.0 & 3.5 & 100 & 89.1 & 3.6 & 7.3 & 100 \\
\hline
\end{tabular}

Source: Calculations from unit level data PLFS 2018-19 and survey on employment \& unemployment 2011-12

from 8 to $15.5 \%$. The increase is evident across all types of workers, i.e. the selfemployed, regular salaried/wage and casual wage labour. There has been a miniscule increase in the share of urban-rural stream among those living in urban areas.

\section{Patterns in Commuting}

Having established the increased importance of commuting in the decade of 2010, the ensuing discussion is based on PLFS 2018-2019. In the ensuing discussion, we focus primarily on the segment of workers for whom the question of commuting is applicable, i.e. workers not engaged in farming.

The construction sector continues to be an important employer, and the share of jobs in manufacturing is similar to that of construction. Just over $57 \%$ of the nonfarm workers are employed in construction (Section F), manufacturing (Section C) and Wholesale and retail trade (Section G) (Fig. 1). Nearly 21\% are employed in transportation and storage (Section $\mathrm{H}$ ), education (Section P), and agriculture, forestry and fishing \& mining and quarrying (Section A\&B).

In Table 3, we provide the distribution of workers by place of residence and location of work within each section of industry. It is not surprising that the proportion of workers without a fixed place of work is miniscule in manufacturing. In contrast, $28 \%$ of workers engaged in transportation and storage and $13.5 \%$ of workers in construction do not have a fixed place of work. Among rural and urban workers without a fixed place of work $72 \%$ and $56 \%$, respectively, are in construction or transportation and storage (Table 4). These averages are in conformity with what one might expect. rural-urban commuters are present in manufacturing and construction, wholesale and retail trade, transportation and storage and education. We find that 


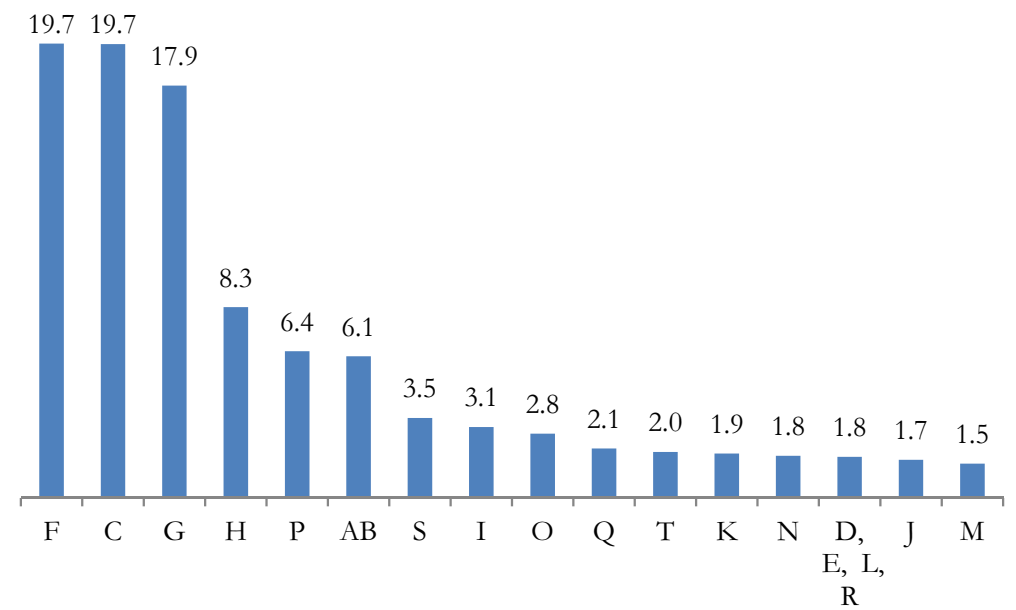

Fig. 1 Industry of work for non-farm workers in 2018-2019 Source: Calculations from unit level data PLFS 2018-19

$61 \%$ of rural-urban commuters and $56 \%$ of urban-rural commuters are employed in manufacturing, wholesale and retail trade and construction (Table 4).

Moving on to individual characteristics the select patterns that merge from the data are as follows. In rural areas, individuals from scheduled tribe household are least likely to commute from rural to urban areas for work. In both rural and urban areas, the share of workers without a fixed place of work is lowest among individuals from other social groups. Men are more likely than women to commute from rural to urban areas. Women are unlikely to be engaged in work which has no fixed place. In rural India, the share of rural-urban commuters is highest among the unmarried. The younger cohort of workers (15-24 years) living in rural India is more likely to commute to urban areas. Three inter-related patterns are evident on association between educational attainment and type of worker (Table 5). First, the proportion of rural-urban commuting workers is the lowest among those who are below primary or not literate and highest in case of those who have completed higher secondary or diploma course or are at least a graduate. Second, as a mirror image, the share of workers who report no fixed place of work is the lowest among who are at least a graduate. Third, in urban India, proportion of workers without a fixed place of work is highest among those who are not literate or below primary.

Among the major states, the share of rural-urban workers engaged in nonfarm activities is highest in Haryana followed by Punjab. In Karnataka, Kerala, Tamil Nadu and Uttar Pradesh too the share of rural-urban commuting workers is higher than the national average (Fig. 2). We next highlight the shares of different states in different types of workers. Nineteen states account for nearly $97 \%$ of total rural-urban commuting workers. Uttar Pradesh and Tamil Nadu account for $15 \%$ and $11 \%$ of total rural-urban commuting workers (Fig. 3). In fact, five NSS regions account for $27 \%$ of rural-urban commuters. These regions are Eastern Haryana (061), Northern Upper Ganga Plain Uttar Pradesh (091), Eastern Uttar Pradesh 
Table 3 Place of residence and work by section of NIC-2008 of non-farm workers

\begin{tabular}{|c|c|c|c|c|c|c|c|}
\hline Section & $\mathrm{R}-\mathrm{R}$ & $\mathrm{R}-\mathrm{U}$ & $\mathrm{R}-\mathrm{NF}$ & U-U & U-R & U-NF & Total \\
\hline $\mathrm{A} \& \mathrm{~B}$ & 77.3 & 2.2 & 4.8 & 12.7 & 1.0 & 2.1 & 100 \\
\hline $\mathrm{C}$ & 34.9 & 9.0 & 1.1 & 52.6 & 1.3 & 1.0 & 100 \\
\hline D\&E & 30.0 & 11.3 & 2.2 & 50.2 & 0.8 & 5.6 & 100 \\
\hline $\mathrm{F}$ & 56.5 & 9.0 & 9.7 & 20.3 & 0.7 & 3.8 & 100 \\
\hline G & 37.0 & 8.7 & 1.7 & 48.3 & 1.1 & 3.2 & 100 \\
\hline $\mathrm{H}$ & 32.4 & 9.1 & 13.9 & 29.9 & 0.6 & 14.1 & 100 \\
\hline I & 32.3 & 10.1 & 1.6 & 50.6 & 0.5 & 4.8 & 100 \\
\hline $\mathrm{J}$ & 6.8 & 4.8 & 1.1 & 85.8 & 0.6 & 0.9 & 100 \\
\hline $\mathrm{K}$ & 13.8 & 10.8 & 0.7 & 72.2 & 0.8 & 1.8 & 100 \\
\hline $\mathrm{L}$ & 14.4 & 4.6 & 2.1 & 65.8 & 2.2 & 11.0 & 100 \\
\hline M & 14.7 & 7.9 & 1.2 & 72.7 & 1.0 & 2.5 & 100 \\
\hline $\mathrm{N}$ & 20.4 & 10.9 & 3.3 & 62.7 & 0.6 & 2.2 & 100 \\
\hline $\mathrm{O}$ & 35.6 & 10.1 & 0.0 & 53.3 & 1.1 & 0.0 & 100 \\
\hline $\mathrm{P}$ & 46.9 & 8.3 & 0.2 & 42.0 & 2.7 & 0.1 & 100 \\
\hline Q & 28.4 & 10.3 & 0.4 & 59.0 & 1.2 & 0.6 & 100 \\
\hline $\mathrm{R}$ & 23.9 & 3.1 & 11.6 & 42.9 & 0.5 & 18.1 & 100 \\
\hline S & 41.0 & 6.4 & 3.7 & 43.8 & 0.8 & 4.4 & 100 \\
\hline $\mathrm{T}$ & 27.3 & 0.0 & 0.0 & 72.3 & 0.3 & 0.0 & 100 \\
\hline Total & 40.9 & 8.3 & 4.3 & 42.0 & 1.0 & 3.4 & 100 \\
\hline
\end{tabular}

Source: Calculations from unit level data PLFS 2018-19

A\&B: agriculture, forestry and fishing \& mining and quarrying, $C$ : manufacturing, D \& E: electricity, gas, steam and air conditioning supply \& water supply; sewerage, waste management and remediation activities, F: construction, G: wholesale and retail trade; repair of motor vehicles and motorcycles, $\mathrm{H}$ : transportation and storage, I: accommodation and food service activities, J: information and communication, $\mathrm{K}$ : financial and insurance activities, L: real estate activities, M: professional, scientific and technical activities, N: administrative and support service activities, $\mathrm{O}$ : public administration and defence; compulsory social security, P: education, Q: human health and social work activities, R: arts, entertainment and recreation, $\mathrm{S}$ : other service activities, T: activities of households as employers; undifferentiated goods and services producing activities of households for own use

(093), Southern Upper Ganga Plain Uttar Pradesh (095), Northern Bihar (101) and Coastal Northern Tamil Nadu (331). Among the cities which are part of Coastal Northern Tamil Nadu are Chennai, Kancheepuram and Vellore. Eastern Haryana is well connected with the Delhi and also comprises of industrial ad employment clusters in Ambala, Sonipat, Gurgaon, Karnal, etc. Sharma (2017) provides insights on the regional patterns observed in the data from 2011 to 2012 survey. Data limitations constrain us from providing a richer description of observed commuting patterns. Bihar, Rajasthan and Uttar Pradesh account for nearly 36\% of rural workers with no fixed place of work, while Maharashtra, Tamil Nadu and Uttar Pradesh account for over $40 \%$ of urban workers without a fixed place of work. These patterns 
Table 4 Industry of work by category of non-farm workers

\begin{tabular}{|c|c|c|c|c|c|c|c|}
\hline & \multicolumn{3}{|c|}{ Rural resident } & \multicolumn{3}{|c|}{ Urban resident } & \multirow{3}{*}{$\begin{array}{l}\text { All } \\
\text { Tota }\end{array}$} \\
\hline & \multicolumn{6}{|c|}{ Place of work } & \\
\hline & $\mathrm{R}$ & $\mathrm{U}$ & $\mathrm{NF}$ & $\mathrm{U}$ & $\mathrm{R}$ & $\mathrm{NF}$ & \\
\hline $\begin{array}{l}\text { Agriculture, forestry and fish- } \\
\text { ing and mining and quarrying }\end{array}$ & 11.6 & 1.6 & 7.0 & 1.9 & 5.7 & 3.7 & 6.1 \\
\hline Manufacturing & 16.8 & 21.3 & 5.2 & 24.6 & 24.7 & 5.9 & 19.7 \\
\hline Construction & 27.1 & 21.5 & 44.8 & 9.5 & 13.1 & 21.6 & 19.7 \\
\hline $\begin{array}{l}\text { Wholesale and retail trade; } \\
\text { repair of motor vehicles and } \\
\text { motorcycles }\end{array}$ & 16.1 & 18.8 & 7.0 & 20.5 & 19.3 & 16.7 & 17.9 \\
\hline Transportation and storage & 6.6 & 9.1 & 26.9 & 5.9 & 4.5 & 33.9 & 8.3 \\
\hline Education & 7.3 & 6.3 & & 6.3 & 16.3 & & 6.4 \\
\hline Other sections & 14.6 & 21.4 & 9.2 & 31.3 & 16.6 & 18.2 & 22.1 \\
\hline Total & 100 & 100 & 100 & 100 & 100 & 100 & 100 \\
\hline
\end{tabular}

Source: Calculations from unit level data PLFS 2018-19

$R$ rural, $U$ urban, $N F$ no fixed place of work

Table 5 Place of residence and work by level of education of non-farm workers

\begin{tabular}{|c|c|c|c|c|c|c|c|c|}
\hline & \multicolumn{4}{|c|}{$\begin{array}{l}\text { Place of work of rural } \\
\text { residents }\end{array}$} & \multicolumn{4}{|c|}{$\begin{array}{l}\text { Place of work of urban } \\
\text { residents }\end{array}$} \\
\hline & $\mathrm{R}$ & $\mathrm{U}$ & $\mathrm{NF}$ & Total & $\mathrm{U}$ & $\mathrm{R}$ & $\mathrm{NF}$ & Total \\
\hline Not literate & 80.6 & 9.8 & 9.6 & 100 & 84.6 & 2.6 & 12.8 & 100 \\
\hline Below primary & 83.1 & 8.5 & 8.4 & 100 & 86.8 & 1.9 & 11.3 & 100 \\
\hline Primary & 76.8 & 13.3 & 9.9 & 100 & 86.2 & 2.1 & 11.7 & 100 \\
\hline Middle & 76.6 & 14.1 & 9.3 & 100 & 88.4 & 1.8 & 9.8 & 100 \\
\hline Secondary & 75.2 & 17.2 & 7.6 & 100 & 90.0 & 1.8 & 8.1 & 100 \\
\hline $\begin{array}{l}\text { Higher second- } \\
\text { ary/diploma/ } \\
\text { certificate } \\
\text { course }\end{array}$ & 71.6 & 23.3 & 5.1 & 100 & 92.9 & 2.3 & 4.8 & 100 \\
\hline $\begin{array}{l}\text { Graduate/post- } \\
\text { graduate and } \\
\text { above }\end{array}$ & 71.8 & 25.4 & 2.8 & 100 & 95.6 & 2.6 & 1.7 & 100 \\
\hline Total & 76.5 & 15.5 & 8.0 & 90.4 & 2.2 & 7.4 & 90.4 & 100 \\
\hline
\end{tabular}

Source: Calculations from unit level data PLFS 2018-19

$R$ rural, $U$ urban, $N F$ no fixed place

are consistent with the share of these groups of states in India's total rural and urban population.

Having discussed key sub-national patterns in commuting and how commuting varies across individuals with different characteristics, we conclude this section by focusing on the importance of rural-urban commuting to total rural earnings. Unlike the EUS which did not collect information on earnings from self-employment, the PLFS collected information on earnings of regular wage/salary, casual labour and 


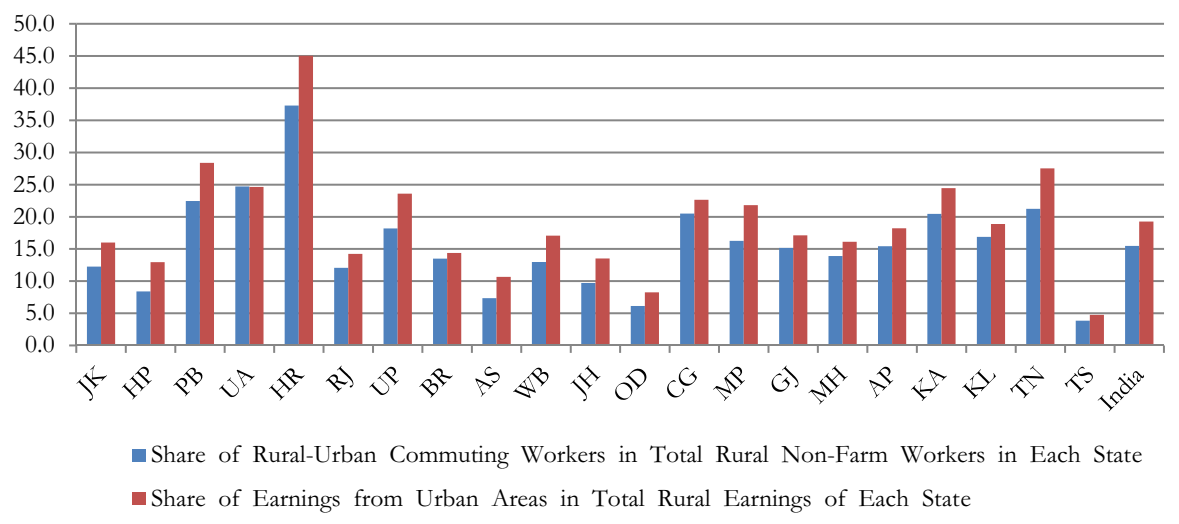

Fig. 2 State-level pattern in rural-urban commuting and corresponding share of earnings Source: Calculations from unit level data PLFS 2018-19

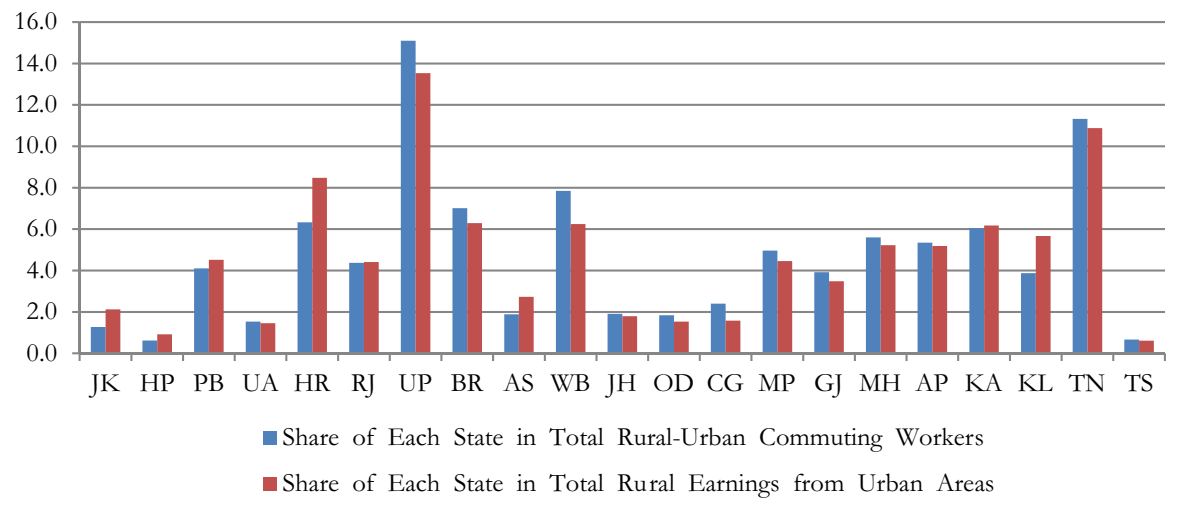

Fig. 3 State's share in all India rural-urban commuters and corresponding share in all India earnings Source: Calculations from unit level data PLFS 2018-19

self-employment. This permits us to create a more complete picture of the earnings profile. The share of earnings of rural residents from working in rural, urban and having no fixed place of work is $72.8,19.3$ and $7.9 \%$, respectively. The share of earnings of urban residents from working in rural, urban and having no fixed place of work is $2.3,92.7$ and $5.1 \%$, respectively. We calculate the share of earnings in each state that can be attributed to commuting. In Fig. 2, we present the share of earnings from urban in total rural earnings of the states. What is striking is that the share of rural-urban commuters in non-farm rural workers in each state is less that the share of urban earnings in total rural earnings of each state. The importance of earnings from rural-urban commuting is clearly apparent for Haryana, Punjab and Tamil Nadu. The relative importance of earnings of rural-urban commuters varies across NSS regions (Fig. 4).

In Fig. 3, we also present the share of each state in all India total earnings from urban in all India total rural earnings. The fact that Uttar Pradesh accounts for the 


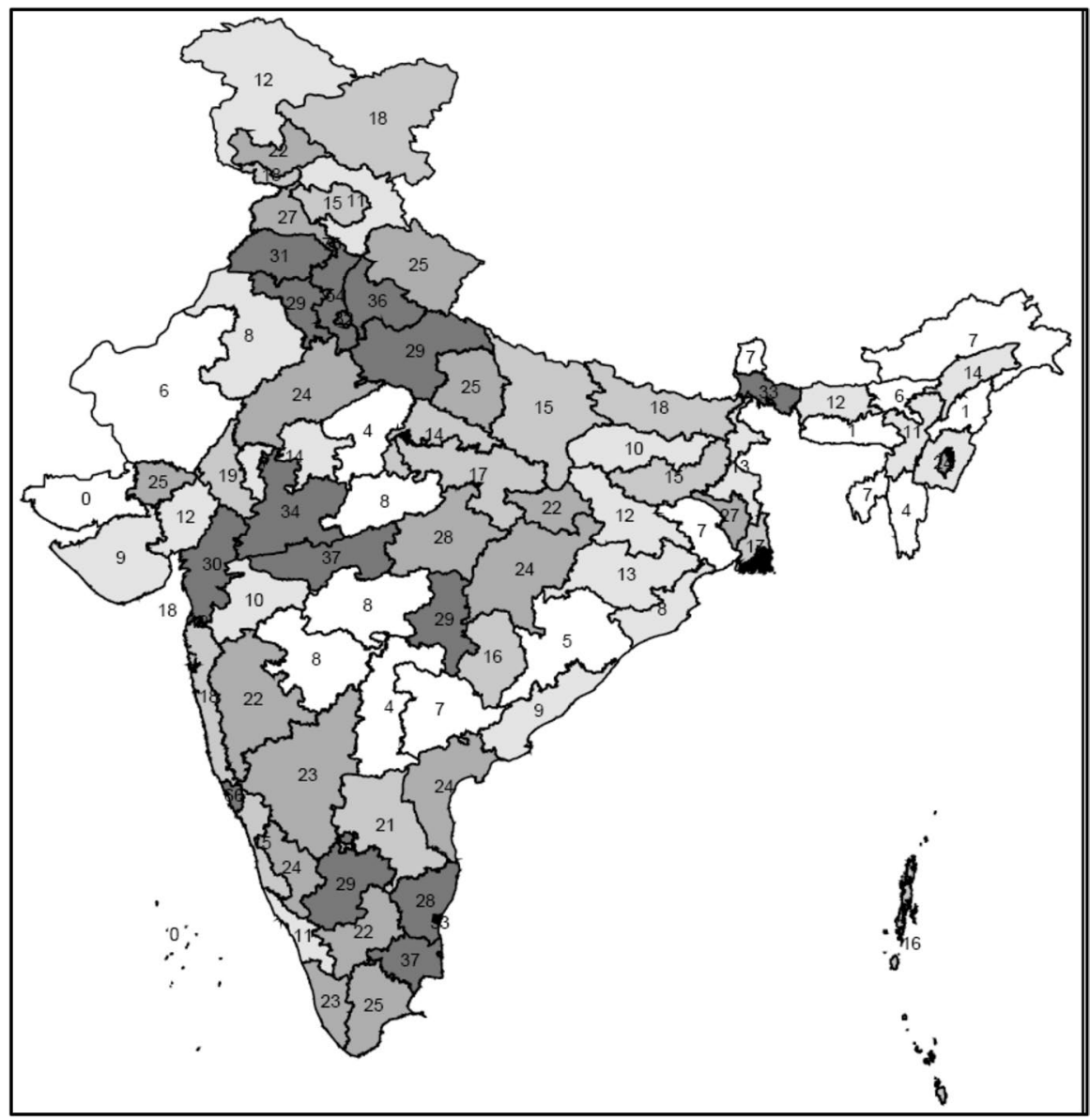

Fig. 4 Share of total rural earnings from rural-urban commuting workers in each national sample survey region Source: Calculations from unit level data PLFS 2018-19

largest share of rural-urban commuters is not surprising since it is India's most populous state. The higher shares of Haryana and Tamil Nadu and the relatively lower share of Maharashtra and West Bengal comes as a surprise since the combined rural population of Haryana and Tamil Nadu is lower than that of rural population of either Maharashtra or West Bengal.

Having discussed the regional patterns and characteristics of commuting workers between rural and urban areas, we present an econometric model to identify the determinants of commuting decision by the individuals in rural and urban India. 


\section{Empirical Model and Results}

We estimate a multinomial model for rural and urban areas separately. For rural areas the outcome variables are live and work in rural (base category), live in rural but workplace is urban, live in rural and has no fixed place of work. For urban areas, the outcome variable are coded as follows: live and work in urban (base category), live in urban but workplace is rural, live in urban and has no fixed place of work.

One might argue that there ought to be a first stage regression on whether an individual is engaged in farming as against other work where the question on place of work is relevant. Conditional on this the second stage would be the multinomial model. Possession of land is probably the most important determinant of being engaged in agriculture and not being required to commute. However, the PLFS does not have information on land holding. Also, in the literature on commuting it is standard practice to ignore those workers engaged in farming.

The explanatory variables can be grouped into the following broad categories, viz. individual, household and regional determinants. Among the individual characteristic are age, gender, marital status, educational attainment and skill level. The household level controls are religion, social group and household size. Among the regional level variables are rural and urban unemployment rate, level of urbanization and classification of jobs. The unemployment rate and classification of jobs are calculated at the NSS region/district level in 2017-2018, for exogeneity purpose

In the literature, it is a standard practice to include level of urbanization of district as a control. Since commuting patterns can cut across district, we do not include the urbanization rate. Instead, we include a measure of rural-urban classification of jobs. We follow the approach outlined by Holmes and Stevens (2004) to classify occupations into three mutually exclusive groups, viz. rural, urban and diffuse. To this end, data from Census of India 2011 are used which has information on 27 and 113 occupations ${ }^{4}$ at the two- and three-digit levels, respectively, according to National Classification of Occupations (NCO) 2004 for each of the 640 districts. We consider all occupations including those where location of place of work is not relevant. First, all districts (arranged in ascending order of total workers) are divided into 4 quartiles based on total employment. Quartiles 1 and 2 are less urban quartiles compared to quartiles 3 and 4 since the share of urban population and worker-to-population ratio increases across the quartiles. An occupation is classified as urban (rural) if it is overrepresented in the most (least) urban quartiles. To deduce this, we calculate location quotient for every 2-digit occupation and quartile. The difference in location quotient between Q4 and Q1, called the urbanness measure, will reflect the tendency of the occupation to locate in more urban or less urban quartiles. Its higher positive (negative) value implies that the occupation is specialized in the most (least) urban areas. Arranging the 2-digit occupations by their urbanness measure, we find discrete gaps in the measure between $0.34 \& 0.19$, and $-0.22 \&$ $-0.42 .{ }^{5}$ Occupations with urbanness measure greater than 0.19 are classified as urban,

\footnotetext{
${ }^{4}$ This includes excludes agricultural labourers, cultivators and workers whose occupations are not classified.

${ }^{5}$ These cutoffs are determined by also keeping in mind the LQ for an occupation in each quartile. All occupations thus classified as urban generally have LQ greater than 1 in Q3 and Q4, whereas rural occupations have LQ greater than 1 in Q1 and Q2.
} 
whereas occupations with urbanness measure less than -0.22 are classified as rural. All other occupations are labelled as diffuse. The distribution of workers in rural, urban and diffuse occupations is $33 \%, 31 \%$ and $36 \%$, respectively. We then calculate the urbanness measure for 3-digit occupations. However, it is difficult to find discrete gaps in the urbanness measure of 113 occupations. Therefore, the threshold in urbanness measure of 3-digit occupations is defined using the share of workers in rural, diffused and urban occupations as per the 2-digit classification. Having classified the 113 occupations into three groups, we calculate using the PLFS 2018-2019 data the share of occupations in each NSS region which are rural, urban and diffuse.

The summary statistics of variables used in the analysis are presented in Table 6.

We first estimate a parsimonious model where we only include the lagged rural and urban unemployment rate measured at the NSS region level and the percentage of workers in occupations that can be characterized as rural and urban. We also include state dummies. Of interest is the coefficient on the unemployment rate, and these are in line with expectations (Table 7). In the rural model, we find the coefficient (relative risk ratio) on rural and unemployment rate to be greater than one and less than one, respectively, and statistically significant. This suggests that high rural unemployment rate and low urban unemployment rate act as a push and pull factor respectively. The converse is true in terms of urban-rural commuting. A priori we do not have a conjecture on how unemployment rate is correlated with jobs without a fixed place of work. We find that if urban unemployment rate is low then the odds of having a no fixed place of work are lower in rural and urban India.

When we include household and individual characteristics as additional controls, the effect of rural and urban unemployment on rural-urban (Table 8) and urban-rural commuting (Table 9) is the same as in the base model. Our results indicate that the association between unemployment rate and commuting is similar in nature to that of unemployment rate and decision to migrate (Pissarides and Wadsworth 1989). In terms of interpreting the coefficients on proportion of jobs which can be categorized as rural or urban, the excluded category is proportion of jobs that can be classified as diffuse. Also, recall that since we have considered even those not commuting while classifying occupations the proportion of rural occupations includes farming. We find that higher the proportion of urban jobs the more is likely to observe rural-urban commuting (Table 8) and less of urban-rural commuting (Table 9).

We find that individuals in the age group 35-44 and 45-59 years are less likely to commute from rural to urban. More educated people in rural India are more likely to commute from rural to urban and are less likely to be engaged in work without a fixed place of work.

Women are less likely to commute from rural to urban or be engaged in work without a fixed place of work. That women are less likely to travel to work is also corroborated by estimates from NSO's Survey of "Drinking Water, Sanitation, Hygiene and Housing Condition" conducted between July and December $2018 .{ }^{6}$ In

\footnotetext{
${ }^{6}$ As per estimates from Census of India 2011, among male and female workers who are not cultivators and agricultural labourers or engaged in household industry nearly $26 \%$ and $45 \%$ did not travel.
} 
Table 6 Summary statistics for rural and urban non-farm workers

Place of residence: rural

Place of residence: urban

Mean Standard Min. Max. Mean Standard Min. Max. deviation deviation

Location of work

Rural

Urban

No fixed

Employment status

Self-employed

Regular wage/salaried

Casual labour

Industry of work

Agriculture, forestry \& mining (A\&B)

Manufacturing (C)

Construction (F)

Wholesale and retail trade $(\mathrm{G})$

$\begin{array}{rrrrrrrr}0.77 & - & 0 & 1 & 0.03 & - & 0 & 1 \\ 0.15 & - & 0 & 1 & 0.90 & - & 0 & 1 \\ 0.08 & - & 0 & 1 & 0.07 & - & 0 & 1\end{array}$

Transportation and storage $(\mathrm{H})$

Accommodation and food services (I)

Education (P)

Other service activities (S)

Others

$\begin{array}{llllllll}0.38 & - & 0 & 1 & 0.36 & - & 0 & 1 \\ 0.34 & - & 0 & 1 & 0.52 & - & 0 & 1 \\ 0.28 & - & 0 & 1 & 0.12 & - & 0 & 1\end{array}$

Age group

$15-24$
$25-34$
$35-44$
$45-59$

Education level

Not literate

Below primary

Primary

Middle

Secondary

Higher secondary/diploma/certificate

Graduation or above

0.09

$0.16-$

$0.24-$

$0.16 \quad-$

$0.09-$

$0.02 \quad-$

$0.08-$

$0.03-$

0.13

$\begin{array}{llllllll}0.14 & - & 0 & 1 & 0.12 & - & 0 & 1 \\ 0.30 & - & 0 & 1 & 0.29 & - & 0 & 1 \\ 0.30 & - & 0 & 1 & 0.29 & - & 0 & 1 \\ 0.27 & - & 0 & 1 & 0.30 & - & 0 & 1\end{array}$

Gender

Male

Female

$\begin{array}{llllllll}0.13 & - & 0 & 1 & 0.09 & - & 0 & 1 \\ 0.04 & - & 0 & 1 & 0.03 & - & 0 & 1 \\ 0.13 & - & 0 & 1 & 0.10 & - & 0 & 1 \\ 0.26 & - & 0 & 1 & 0.21 & - & 0 & 1 \\ 0.18 & - & 0 & 1 & 0.16 & - & 0 & 1 \\ 0.14 & - & 0 & 1 & 0.15 & - & 0 & 1 \\ 0.11 & - & 0 & 1 & 0.26 & - & 0 & 1\end{array}$

Marital status

Unmarried

Married

Other (widowed/divorced)

$\begin{array}{llllllll}0.80 & - & 0 & 1 & 0.80 & - & 0 & 1 \\ 0.20 & - & 0 & 1 & 0.20 & - & 0 & 1\end{array}$


Table 6 (continued)

\begin{tabular}{|c|c|c|c|c|c|c|c|c|}
\hline & \multicolumn{4}{|c|}{ Place of residence: rural } & \multicolumn{4}{|c|}{ Place of residence: urban } \\
\hline & Mean & $\begin{array}{l}\text { Standard } \\
\text { deviation }\end{array}$ & Min. & Max. & Mean & $\begin{array}{l}\text { Standard } \\
\text { deviation }\end{array}$ & Min. & Max. \\
\hline \multicolumn{9}{|l|}{ Household size } \\
\hline 1-2 members & 0.07 & - & 0 & 1 & 0.11 & - & 0 & 1 \\
\hline $3-5$ members & 0.66 & - & 0 & 1 & 0.65 & - & 0 & 1 \\
\hline $6-10$ members & 0.26 & - & 0 & 1 & 0.23 & - & 0 & 1 \\
\hline More than 10 members & 0.02 & - & 0 & 1 & 0.02 & - & 0 & 1 \\
\hline \multicolumn{9}{|l|}{ Religion } \\
\hline Hindu & 0.74 & - & 0 & 1 & 0.73 & - & 0 & 1 \\
\hline Muslim & 0.14 & - & 0 & 1 & 0.16 & - & 0 & 1 \\
\hline Christian & 0.07 & - & 0 & 1 & 0.07 & - & 0 & 1 \\
\hline Sikh & 0.03 & - & 0 & 1 & 0.02 & - & 0 & 1 \\
\hline Others & 0.02 & - & 0 & 1 & 0.02 & - & 0 & 1 \\
\hline \multicolumn{9}{|l|}{ Social group } \\
\hline Scheduled tribe & 0.15 & - & 0 & 1 & 0.08 & - & 0 & 1 \\
\hline Scheduled caste & 0.22 & - & 0 & 1 & 0.14 & - & 0 & 1 \\
\hline Other backward class & 0.39 & - & 0 & 1 & 0.40 & - & 0 & 1 \\
\hline Others & 0.23 & - & 0 & 1 & 0.38 & - & 0 & 1 \\
\hline Observations & 40,596 & & & & 53,929 & & & \\
\hline
\end{tabular}

Source: Calculations from unit level data PLFS 2018-19

nearly $32 \%$ of rural and $43 \%$ of urban households, no woman travels for work. If at all women travel, it is within a distance of less than $1 \mathrm{~km}$ or between 1 and $5 \mathrm{~km}$. In contrast in over $8 \%$ and $14 \%$ of rural and urban households, the maximum distance travelled by a male member is over $15 \mathrm{~km}$ (Table 10).

The results on individual's work characteristics are consistent with summary statistics. Compared to those who are regular wage or salaried, the self-employed and those engaged as casual labour are more likely to commute or have no fixed place of work. Compared to those working in construction, individuals engaged in manufacturing, wholesale and retail trade, transportation and storage, or accommodation and food service activities are more likely to commute to rural areas.

These results highlight the role of local labour market conditions at origin and destination measured by unemployment rate, spatial distribution of economic activities (using the classification indicator of jobs) as well as nature of employment are key determinants for the commuting decision of individuals in both rural and urban India. 
Table 7 Relative risk ratio (RRR) from multinomial model: workplace location of rural and urban nonfarm workers

Rural sample

\begin{tabular}{|c|c|c|c|c|}
\hline & \multicolumn{4}{|c|}{ Base category: rural workplace } \\
\hline & \multicolumn{2}{|c|}{ Urban work place } & \multicolumn{2}{|c|}{ No fixed place of work } \\
\hline & RRR & SE & RRR & SE \\
\hline Rural unemployment rate & $1.020 * * *$ & 0.007 & $1.046 * * *$ & 0.009 \\
\hline Urban unemployment rate & $0.997 * * *$ & 0.001 & $0.988 * * *$ & 0.002 \\
\hline Proportion of rural occupations & $1.021 * * *$ & 0.003 & $1.022 * * *$ & 0.004 \\
\hline Proportion of urban occupations & $1.025 * * *$ & 0.004 & $1.009 *$ & 0.005 \\
\hline$N=40,596$ & & & & \\
\hline
\end{tabular}

Urban sample

\begin{tabular}{|c|c|c|c|c|}
\hline & \multicolumn{4}{|c|}{ Base category: urban workplace } \\
\hline & \multicolumn{2}{|c|}{ Rural work place } & \multicolumn{2}{|c|}{ No fixed place of work } \\
\hline & RRR & SE & RRR & SE \\
\hline Rural unemployment rate & $0.929 * * *$ & 0.013 & $1.066 * * *$ & 0.009 \\
\hline Urban unemployment rate & 1.001 & 0.002 & $0.988 * * *$ & 0.002 \\
\hline Proportion of rural occupations & $1.015 * * *$ & 0.006 & 0.999 & 0.004 \\
\hline $\begin{array}{l}\text { Proportion of urban occupations } \\
N=53,929\end{array}$ & $0.975 * * *$ & 0.008 & $0.965 * * *$ & 0.005 \\
\hline
\end{tabular}

State dummies included. Omitted category is proportion of occupations that can be classified as diffuse. The unemployment rate and the proportion of rural and urban occupations are measured at the level of National Sample Survey Region

$* * *$ Significant at $1 \%, *$ Significant at $10 \%$

\section{Discussion}

In this paper, we have established the importance of rural-urban linkages both in terms of numbers and share of earnings in rural India households from the urban. In the decade of 2010, the number rural urban commuters and those without a fixed place of work have more than doubled. These estimates ignore those who move within the rural or urban areas. While it is not possible to quantify the economic output attributable to the workers commuting from rural to urban, we are able to estimate the share of earnings from urban in total non-farm rural earnings to be nearly $20 \%$. This average as we point out in the paper masks substantial variation across states. We find that high rural and low urban unemployment rates act as a push and pull factor for commuting between rural and urban areas. A contribution of this paper is the use of classification of occupations as rural, urban or diffuse to analyse the pattern of commuting. We find that regions with more urban occupations will see more rural-urban commuting, and this will be lower in regions with more rural occupations. 
Table 8 Relative risk ratio (RRR) from multinomial model: workplace location of rural non-farm workers

\begin{tabular}{|c|c|c|c|c|}
\hline & \multicolumn{4}{|c|}{ Base category: rural workplace } \\
\hline & \multicolumn{2}{|c|}{ Urban work place } & \multicolumn{2}{|c|}{ No fixed place of work } \\
\hline & RRR & SE & RRR & SE \\
\hline Rural unemployment rate & $1.024 * * *$ & 0.007 & $1.034 * * *$ & 0.010 \\
\hline Urban unemployment rate & $0.994 * * *$ & 0.001 & $0.987 * * *$ & 0.002 \\
\hline Proportion of rural occupations & $1.022 * * *$ & 0.003 & $1.025 * * *$ & 0.005 \\
\hline Proportion of urban occupations & $1.017 * * *$ & 0.004 & $1.019 * * *$ & 0.006 \\
\hline \multicolumn{5}{|l|}{ Principal status: regular wage/salaried } \\
\hline Self-employed & $0.207 * * *$ & 0.010 & $1.647 * * *$ & 0.105 \\
\hline Casual labour & $0.529 * * *$ & 0.031 & $2.099 * * *$ & 0.162 \\
\hline \multicolumn{5}{|l|}{ Industry of work: construction } \\
\hline Section AB & $0.217 * * *$ & 0.028 & $0.722 * * *$ & 0.064 \\
\hline Section C & $1.498 * * *$ & 0.095 & $0.335^{* * *}$ & 0.034 \\
\hline Section $\mathrm{G}$ & $2.155^{* * *}$ & 0.149 & $0.373^{* * *}$ & 0.036 \\
\hline Section $\mathrm{H}$ & $1.448 * * *$ & 0.112 & $4.930^{* * *}$ & 0.342 \\
\hline Section I & $1.948 * * *$ & 0.202 & $0.500^{* * *}$ & 0.090 \\
\hline Section $\mathrm{O}$ & 0.981 & 0.091 & $0.000^{* * *}$ & 0.000 \\
\hline Section P & $0.452 * * *$ & 0.041 & $0.044 * * *$ & 0.019 \\
\hline Section Q & $1.464 * * *$ & 0.161 & $0.383 * * *$ & 0.129 \\
\hline Section S & $1.318 * *$ & 0.155 & 0.972 & 0.124 \\
\hline Section others & $1.388 * * *$ & 0.108 & 0.939 & 0.102 \\
\hline \multicolumn{5}{|l|}{ Age group (15-24 years) } \\
\hline $25-34$ & 0.995 & 0.053 & 1.124 & 0.083 \\
\hline $35-44$ & $0.894 *$ & 0.055 & 1.023 & 0.084 \\
\hline $45-59$ & $0.879 * *$ & 0.058 & 0.930 & 0.081 \\
\hline \multicolumn{5}{|l|}{ Education level (not literate) } \\
\hline Below primary & $0.782 * *$ & 0.081 & 0.954 & 0.095 \\
\hline Primary & 1.002 & 0.071 & $0.823 * * *$ & 0.061 \\
\hline Middle & $1.132 * *$ & 0.071 & $0.785^{* * *}$ & 0.053 \\
\hline Secondary & $1.239 * * *$ & 0.082 & $0.757 * * *$ & 0.056 \\
\hline Higher secondary/diploma/certificate & $1.403 * * *$ & 0.097 & $0.648 * * *$ & 0.057 \\
\hline Graduation or above & $1.801 * * *$ & 0.136 & $0.514 * * *$ & 0.065 \\
\hline \multicolumn{5}{|l|}{ Gender (male) } \\
\hline Female & $0.823 * *$ & 0.079 & $0.292 * * *$ & 0.092 \\
\hline \multicolumn{5}{|l|}{ Marital status (unmarried) } \\
\hline Married & 0.959 & 0.048 & 0.969 & 0.064 \\
\hline Other (widowed/divorced) & 0.821 & 0.130 & 1.011 & 0.175 \\
\hline Married $*$ female & $0.467 * * *$ & 0.052 & 0.778 & 0.259 \\
\hline Other*female & 0.839 & 0.176 & 0.999 & 0.415 \\
\hline
\end{tabular}

Household religion, social group, household size and state dummies are included as controls. Omitted category is proportion of occupations that can be classified as diffuse. The unemployment rate and the proportion of rural and urban occupations are measured at the level of National Sample Survey Region. $N=40,596$. ***Significant at $1 \%$, *Significant at $10 \%$ 
Broadly, the findings in this paper clearly indicate that we need a broader conversation on labour mobility encompassing both migration and commuting. ${ }^{7}$ The insights from Datta et al. (2014) contrasting the earnings in two villages in Bihar are particularly informative. They argue that ease of access to urban labour markets made commuting attractive and earnings from commuting were higher than remittances from migrants. "If only income within the village (including commuting) is taken into account, the mean household income in Chandkura (where commuting is important) was $78 \%$ higher than in Mahisham (where migration is more important). After adding in remittances, the gap is reduced to $27 \%$ (these are averages for the whole village, including both migrant and non-migrant households)" (p. 9).

Due to data limitations, the evidence on the mechanisms and understanding welfare implications of place of work is limited. Recent papers have established an association between construction of roads with declining participation in agriculture sector and increase in non-farm employment (Asher and Novosad 2020; Lei et al. 2019). The importance of inter-sectoral linkages to the pace of poverty reduction in rural and urban India was established by Datt et al. (2020). Sharma and Chandrasekhar (2016) find that households with rural-urban commuters have higher dietary diversity while households with workers having no fixed place of work are worse off than households with no commuters. Beyond these there are many open questions including whether there is a wage premium to commuting, how the labour market outcomes in receiving regions are affected because of commuting and whether commuting and migration are substitutes. The Government of India's Economic Survey 2016-2017 devoted an entire chapter to the issue of worker mobility, viz. commuting and migration. One of the key takeaways from that chapter is the need to address data gaps. The question on location of workplaces in recent surveys is less informative in comparison to what was asked in survey of employment and unemployment in 1993-1994. That particular survey sought more detailed information on place of work which was coded as follows: same village or town, another village or another town. The distance travelled was coded as less than $5 \mathrm{~km}, 5-20 \mathrm{~km}$ and above $20 \mathrm{~km}$. While the conjecture that rural areas characterized by commuting will have lower migration rates is compelling, one is unable to answer this question with data from nationally representative surveys conducted by India's NSO. The reason for this is the absence of surveys with information on both migration and place of work. Future surveys conducted by India's NSO need to prioritize a set of questions that would capture the nature and strength of rural-urban linkages.

\footnotetext{
7 Srivastava (2020) provides an estimate of the number of workers and in particular migrants who are likely to have been affected by the COVID-19-induced lockdown measures announced by the central and state governments in India. The commuting workers are a subset of the total number of vulnerable workers who were affected by the lockdown. Because of restrictions on travel and lack of public transportation, the impact on the commuting workers would have been particularly severe. Using Facebook mobile users' data, Mukhopadhyay and Roy (2020) map the lockdown effects in India. They find a decrease in the number of commuters and also highlight the fact that the extent of decline varies across the states.
} 
Table 9 Relative risk ratio (RRR) from multinomial model: workplace location of urban non-farm workers

\begin{tabular}{|c|c|c|c|c|}
\hline & \multicolumn{4}{|c|}{ Base category: urban workplace } \\
\hline & \multicolumn{2}{|c|}{ Rural work place } & \multicolumn{2}{|c|}{ No fixed place of work } \\
\hline & RRR & SE & RRR & SE \\
\hline Rural unemployment rate & $0.926 * * * *$ & 0.013 & $1.075 * * *$ & 0.011 \\
\hline Urban unemployment rate & $1.004 *$ & 0.002 & $0.989 * * *$ & 0.002 \\
\hline Proportion of rural occupations & 1.010 & 0.006 & 0.998 & 0.004 \\
\hline Proportion of urban occupations & $0.977 * * *$ & 0.008 & $0.978 * * *$ & 0.006 \\
\hline \multicolumn{5}{|l|}{ Principal status: regular wage/salaried } \\
\hline Self-employed & $1.725 * * *$ & 0.115 & $7.472 * * *$ & 0.438 \\
\hline Casual labour & $1.639 * * *$ & 0.172 & $7.823 * * *$ & 0.583 \\
\hline \multicolumn{5}{|l|}{ Industry of work: construction } \\
\hline Section $\mathrm{AB}$ & $2.748 * * *$ & 0.378 & $1.303 * * *$ & 0.136 \\
\hline Section $\mathrm{C}$ & 0.957 & 0.103 & $0.229 * * *$ & 0.020 \\
\hline Section G & $0.676^{* * *}$ & 0.076 & $0.438 * * *$ & 0.031 \\
\hline Section $\mathrm{H}$ & $0.692 * *$ & 0.108 & $4.853 * * *$ & 0.320 \\
\hline Section I & $0.480 * * *$ & 0.096 & $0.598 * * *$ & 0.065 \\
\hline Section $\mathrm{P}$ & $2.029 * * *$ & 0.267 & $0.159 * * *$ & 0.055 \\
\hline Section $\mathrm{S}$ & $0.520 * * *$ & 0.103 & $0.830^{*}$ & 0.083 \\
\hline Section others & $0.594 * * *$ & 0.072 & $0.796 * * *$ & 0.065 \\
\hline \multicolumn{5}{|l|}{ Age group (15-24 years) } \\
\hline $25-34$ & 1.072 & 0.119 & 0.999 & 0.075 \\
\hline $35-44$ & 1.101 & 0.133 & 1.011 & 0.084 \\
\hline $45-59$ & 1.156 & 0.141 & 0.922 & 0.078 \\
\hline \multicolumn{5}{|l|}{ Education level (not literate) } \\
\hline Below primary & $0.737^{*}$ & 0.136 & 0.926 & 0.091 \\
\hline Primary & 0.857 & 0.108 & 0.988 & 0.072 \\
\hline Middle & $0.822 *$ & 0.093 & $0.794 * * *$ & 0.052 \\
\hline Secondary & 0.980 & 0.115 & $0.757 * * *$ & 0.054 \\
\hline Higher secondary/diploma/certificate & 1.156 & 0.136 & $0.545 * * *$ & 0.043 \\
\hline Graduation or above & 1.150 & 0.132 & $0.298 * * *$ & 0.027 \\
\hline \multicolumn{5}{|l|}{ Gender (male) } \\
\hline Female & 0.882 & 0.141 & $0.332 * * *$ & 0.078 \\
\hline \multicolumn{5}{|l|}{ Marital status (unmarried) } \\
\hline Married & 1.086 & 0.102 & 0.961 & 0.061 \\
\hline Other (widowed/divorced) & 1.436 & 0.352 & 1.004 & 0.161 \\
\hline Married $*$ female & 1.129 & 0.196 & 1.147 & 0.285 \\
\hline Other*female & 0.741 & 0.237 & 1.422 & 0.441 \\
\hline
\end{tabular}

Household religion, social group, household size and state dummies are included as controls. Omitted category is proportion of occupations that can be classified as diffuse. The unemployment rate and the proportion of rural and urban occupations are measured at the level of National Sample Survey Region. $\mathrm{N}=53,929 * * *$ Significant at $1 \%, *$ Significant at $10 \%$ 
Table 10 Distribution of households by maximum distance normally travelled to place of work

\begin{tabular}{lrrrrr}
\hline & \multicolumn{2}{l}{ Men } & & \multicolumn{2}{l}{ Women } \\
\cline { 2 - 3 } \cline { 6 - 6 } & \multicolumn{1}{l}{ Rural } & Urban & & Rural & Urban \\
\hline Not required to travel & 8.95 & 8.67 & & 31.76 & 43.15 \\
$<1 \mathrm{~km}$ & 21.40 & 12.96 & & 23.68 & 13.36 \\
$1-5 \mathrm{~km}$ & 43.22 & 33.32 & & 37.55 & 24.63 \\
$5-10 \mathrm{~km}$ & 11.80 & 19.56 & & 3.95 & 9.26 \\
$10-15 \mathrm{~km}$ & 6.05 & 11.32 & & 1.44 & 4.94 \\
$15-30 \mathrm{~km}$ & 4.71 & 7.52 & & 1.00 & 3.00 \\
$>30 \mathrm{~km}$ & 3.87 & 6.64 & & 0.64 & 1.66 \\
Total & 100.00 & 100.00 & 100.00 & 100.00 \\
\hline
\end{tabular}

Source: Calculations from unit level data of survey of "drinking water, sanitation, hygiene and housing condition" July-December 2018

Households where there is no earner of a specific gender are excluded from this calculation

Acknowledgements We are grateful to the editors of this special issue for comments on an earlier draft.

\section{Appendix}

See Table 11. 
Table 11 Classification of non-farm workers in rural and urban India by place of residence and work

Place of work of rural residents

$\bar{R} \quad \mathrm{U} \quad \mathrm{NF} \quad \operatorname{Total}(\mathrm{mn})$

(1)

(2)

(3)

82

82.6

12.3

5.1

$69.8 \quad 22.5$

$8.4 \quad 10.2$

$$
63.3
$$

58.8

Haryana

Delhi

8 Rajasthan

9 Uttar Pradesh

10 Bihar

11 Sikkim

12 Arunachal Pradesh

13 Nagaland

14 Manipur

15 Mizoram

16 Tripura

17 Meghalaya

18 Assam

19 West Bengal

20 Jharkhand

21 Odisha

22 Chhattisgarh

23 Madhya Pradesh

24 Gujarat

27 Maharashtra

28 Andhra Pradesh

29 Karnataka

30 Goa

32 Kerala

33 Tamil Nadu

34 Puducherry

36 Telangana

Total All India

$\begin{array}{llcl}58.8 & 37.3 & 3.9 & 3.2 \\ - & - & - & 0.2 \\ 79.9 & 12.1 & 8.0 & 6.8\end{array}$

$\begin{array}{llll}70.6 & 18.2 & 11.2 & 15.6\end{array}$

$\begin{array}{llll}74.5 & 13.5 & 12.0 & 9.8\end{array}$

$\begin{array}{llll}86.1 & 5.4 & 8.5 & 0.1\end{array}$

$\begin{array}{llll}90.4 & 5.4 & 4.2 & 0.2\end{array}$

$\begin{array}{llll}96.4 & 0.6 & 3.0 & 0.2\end{array}$

$\begin{array}{lll}81.6 & 12.9 \quad 5.5\end{array}$

0.4

$92.3 \quad 4.4 \quad 3.2$

0.1

$\begin{array}{lll}80.5 & 5.0 & 14.5\end{array}$

0.6

$91.3 \quad 0.6 \quad 8.1$

0.4

$\begin{array}{lll}78.7 & 7.4 & 13.9\end{array}$

4.8

$82.4 \quad 13.0 \quad 4.6$

11.4

$\begin{array}{llll}81.7 & 9.7 & 8.6 & 3.7\end{array}$

$\begin{array}{llll}88.3 & 6.1 & 5.6 & 5.6\end{array}$

$\begin{array}{llll}75.3 & 20.5 & 4.1 & 2.2\end{array}$

$\begin{array}{llll}77.9 & 16.3 & 5.9 & 5.7\end{array}$

$\begin{array}{llll}76.1 & 15.2 & 8.7 & 4.9\end{array}$

$\begin{array}{llll}80.2 & 13.9 & 5.9 & 7.6\end{array}$

$\begin{array}{llll}81.4 & 15.4 & 3.2 & 6.5\end{array}$

$\begin{array}{llll}67.4 & 20.4 & 12.1 & 5.6\end{array}$

$\begin{array}{llll}39.9 & 60.0 & 0.1 & 0.2\end{array}$

$\begin{array}{llll}75.5 & 16.9 & 7.6 & 4.3\end{array}$

$\begin{array}{llll}72.0 & 21.2 & 6.7 & 10.0\end{array}$

$\begin{array}{llll}49.0 & 43.3 & 7.7 & 0.2\end{array}$

$\begin{array}{llll}88.1 & 3.8 & 8.0 & 3.2\end{array}$

$\begin{array}{llll}76.5 & 15.5 & 8.0 & 121.4\end{array}$

\section{Place of work of urban residents}

\begin{tabular}{llll}
\hline $\mathrm{U}$ & $\mathrm{R}$ & $\mathrm{NF}$ & Total $(\mathrm{mn})$
\end{tabular}

(4) (5) (6)

$\begin{array}{rrrr}91.2 & 3.3 & 5.6 & 0.7 \\ 90.5 & 5.4 & 4.2 & 0.2 \\ 90.4 & 2.0 & 7.6 & 3.3 \\ 88.8 & 2.7 & 8.5 & 0.7 \\ 94.1 & 2.5 & 3.4 & 2.5 \\ 94.0 & 0.3 & 5.7 & 5.4 \\ 90.0 & 2.3 & 7.7 & 4.6 \\ 85.2 & 3.6 & 11.2 & 9.9 \\ 83.7 & 3.7 & 12.6 & 2.0 \\ 91.6 & 2.7 & 5.6 & 0.1 \\ 93.4 & 0.9 & 5.7 & 0.1 \\ 92.8 & 1.0 & 6.3 & 0.1 \\ 85.6 & 7.2 & 7.2 & 0.2 \\ 89.7 & 4.1 & 6.1 & 0.1 \\ 78.3 & 7.7 & 14.1 & 0.2 \\ 92.7 & 0.4 & 6.9 & 0.1 \\ 86.6 & 3.9 & 9.5 & 0.8 \\ 91.8 & 3.3 & 4.9 & 9.2 \\ 87.6 & 2.0 & 10.4 & 1.7 \\ 88.9 & 6.9 & 4.2 & 1.7 \\ 91.2 & 2.0 & 6.8 & 1.4 \\ 92.1 & 1.4 & 6.5 & 5.0 \\ 94.1 & 0.5 & 5.5 & 8.4 \\ 91.1 & 1.3 & 7.6 & 14.0 \\ 89.8 & 4.0 & 6.2 & 5.3 \\ 92.1 & 1.5 & 6.4 & 7.1 \\ 93.1 & 6.3 & 0.6 & 0.3 \\ 91.2 & 2.1 & 6.7 & 4.5 \\ 88.8 & 2.4 & 8.9 & 10.8 \\ 91.9 & 2.8 & 5.2 & 0.3 \\ 98.0 & 1.0 & 11.0 & 4.2 \\ 90.4 & 2.2 & 7.4 & 105.6 \\ & & & \\ 93 \\ 93\end{array}$

Source: Calculations from unit level data PLFS 2018-19

$R$ rural, $U$ urban, $N F$ no fixed. The first pertains to place of residence and second place of work. Columns $1,2 \& 3$ and $4,5 \& 6$ each add up to 100 . We have not reported the estimates for Delhi (Rural), Andaman and Nicobar Islands, Chandigarh, Daman \& Diu, Dadra and Nagar Haveli and Lakshadweep 


\section{References}

Alonso, W. 1964. Location and land use. Cambridge: Harvard University Press.

Andersson, M., N. Lavesson, and T. Niedomysl. 2018. Rural to urban long-distance commuting in Sweden: trends, characteristics and pathways. Journal of rural studies 59: 67-77.

Artis, M., J. Romaní, and J. Suriñach. 2000. Determinants of individual commuting in Catalonia, 19861991: theory and empirical evidence. Urban Studies 37(8): 1431-1450.

Asher, S., and P. Novosad. 2020. Rural roads and local economic development. American Economic Review 110(3): 797-823.

Brueckner, J.K., J.F. Thisse, and Y. Zenou. 1999. Why is central Paris rich and downtown Detroit poor? An amenity-based theory. European economic review 43(1): 91-107.

Chakravorty, S., and S.V. Lall. 2007. Made in India: The economic geography and political economy of industrialization. Oxford: Oxford University Press.

Chandrasekhar, S., M. Naik, and S.N. Roy. 2017. On the importance of triangulating data sets to examine Indians on the move. Economic and Political Weekly 52(47): 60-68.

Datt, G., M. Ravallion, and R. Murgai. 2020. Poverty and growth in India over six decades. American Journal of Agricultural Economics 102(1): 4-27.

Datta, A., G. Rodgers, J. Rodgers, and B.K.N. Singh. 2014. Contrasts in development in Bihar: A tale of two villages. The Journal of Development Studies 50(9): 1197-1208.

Desmet, K., E. Ghani, S. O'Connell, and E. Rossi-Hansberg. 2015. The spatial development of India. Journal of Regional Science 55(1): 10-30.

Diao, X., E. Magalhaes, and J. Silver. 2019. Cities and rural transformation: A spatial analysis of rural livelihoods in Ghana. World Development 121: 141-157.

Douglass, M. 2007. A regional network strategy for reciprocal rural- urban linkages: An agenda for policy research with reference to Indonesia. In The Earthscan reader in rural urban linkages, ed. $\mathrm{C}$. Tacoli, 124-154. London: Earthscan.

Duvivier, C., S. Li, and M.F. Renard. 2013. Are workers close to cities paid higher nonagricultural wages in rural China? Applied Economics 45(30): 4308-4322.

Everitt, J.C., and A.M. Gill. 1993. The social geography of small towns. In The changing social geography of Canadian cities, ed. L.S. Bourne and D.F. Ley, 252-266. Montreal: McGill-Queens Press.

Ghani, E., A.G. Goswami, and W.R. Kerr. 2012. Is India's manufacturing sector moving away from cities? Working paper no. w17992. National Bureau of Economic Research.

Green, A.E., T. Hogarth, and R.E. Shackleton. 1999. Longer distance commuting as a substitute for migration in Britain: A review of trends, issues and implications. International Journal of Population Geography 5(1): 49-67.

Green, M.B., and S.P. Meyer. 1997. An overview of commuting in Canada: With special emphasis on rural commuting and employment. Journal of Rural Studies 13(2): 163-175.

Heyer, J. 2013. Integration into a global production network: Impacts on labour in Tiruppur's rural hinterlands. Oxford Development Studies 41(3): 307-321.

Holmes, T.J., and J.J. Stevens. 2004. Spatial distribution of economic activities in North America. In Handbook of regional and urban economics, Vol. 4, 2797-2843. Elsevier.

Lei, L., S. Desai, and R. Vanneman. 2019. The impact of transportation infrastructure on women's employment in India. Feminist Economics 25(4): 94-125.

Mills, E.S. 1967. An aggregative model of resource allocation in a metropolitan area. The American Economic Review 57(2): 197-210.

Mukhopadhyay, P., and S.N. Roy. 2020. Mapping the lockdown effects in India: How geographers can contribute to tackle COVID-19 diffusion. The Conversation, April 22, 2020.

Muth, R. 1969. Cities and housing: The spatial patterns of urban residential land use. Chicago: Chicago University Press.

National Statistical Office. 2020. Annual report: Periodic labour force survey (PLFS) July 2018-June 2019), Government of India, Ministry of Statistics and Programme Implementation, National Statistical Office, June 2020.

Pissarides, C.A., and J. Wadsworth. 1989. Unemployment and the interregional mobility of labourThe. Economic Journal 99(397): 739-755.

Rowe, F., and M. Bell. 2020. The drivers of long-distance commuting in Chile: The role of the spatial distribution of economic activities, Chapter 6, In Population Change and Impacts in Asia and the Pacific, eds. Jacques Poot and Matthew Roskruge, Springer, pp. 123-149. 
Sharma, A. 2016. Urban proximity and spatial pattern of land use and development in rural India. The Journal of Development Studies 52(11): 1593-1611.

Sharma, A. 2017. Commuting workers and the integration of the rural-urban economy, Chapter 22, In Subaltern Urbanization in India. An Introduction to Ordinary Towns' Dynamics, eds. Eric Denis and Marie-Helene Zerah, Springer, pp. 577-600.

Sharma, A., and S. Chandrasekhar. 2014. Growth of the urban shadow, spatial distribution of economic activities, and commuting by workers in rural and urban India. World Development 61: 154-166.

Sharma, A., and S. Chandrasekhar. 2016. Impact of commuting by workers on household dietary diversity in rural India. Food Policy 59: 34-43.

Shirai, Y., S. Leisz, J. Fox, and A.T. Rambo. 2019. Commuting distances to local non-farm workplaces and out-migration: The case of Northeast Thailand. Asia Pacific Viewpoint 60(3): 280-295.

Srivastava, R. 2020. Understanding circular migration in India: Its nature and dimensions, the crisis under lockdown and the response of the state. WP 04/2020, IHD Working Paper Series, India.

White, M.J. 1988. Location choice and commuting behavior in cities with decentralized employment. Journal of Urban Economics 24(2): 129-152.

Publisher's Note Springer Nature remains neutral with regard to jurisdictional claims in published maps and institutional affiliations. 